\title{
In vitro biocompatibility analysis of two types of titanium surfaces treated by Electric Discharge Machining (EDM)
}

\author{
Análise in vitro da biocompatibilidade de dois tipos de superfícies de titânio tratadas por descarga \\ elétrica (EDM)
}

Análisis in vitro de biocompatibilidad de dos tipos de superficies de titanio tratadas mediante mecanizado por descarga eléctrica (EDM)

Received: 06/22/2021 | Reviewed: 06/29/2021 | Accept: 07/05/2021 | Published: 07/15/2021

\author{
Rogério Ferreira Garcia \\ ORCID: https://orcid.org/0000-0002-8795-5664 \\ Federal University of Uberlândia, Brazil \\ E-mail: dr.rogerioferreira@hotmail.com \\ Isabela Lemos de Lima \\ ORCID: https://orcid.org/0000-003-0953-487X \\ Federal University of Uberlândia, Brazil \\ E-mail: isabela.lemosl@hotmail.com \\ Paloma Soares de Castro \\ ORCID: https://orcid.org/0000-0003-1137-8490 \\ Federal University of Uberlândia, Brazil \\ E-mail: paloma_cp@hotmail.com \\ Luiz Ricardo Goulart \\ ORCID: https://orcid.org/0000-0002-1803-4861 \\ Federal University of Uberlândia, Brazil \\ E-mail: lrgoulart@ufu.br \\ Vivian Alonso-Goulart \\ ORCID: https://orcid.org/0000-0002-2041-0053 \\ Federal University of Uberlândia, Brazil \\ E-mail: vivialonso@hotmail.com \\ Flaviana Soares Rocha \\ ORCID: https://orcid.org/0000-0002-6759-2229 \\ University of Brasília, Brazil \\ E-mail: flavianasoares.rocha@gmail.com \\ Alberto Arnaldo Raslan \\ ORCID: https://orcid.org/0000-0001-9549-9956 \\ Federal University of Uberlândia, Brazil \\ E-mail: 1tm-raslan@ufu.br \\ Letícia de Souza Castro Filice \\ ORCID: https://orcid.org/0000-0003-4300-1575 \\ Federal University of Uberlândia, Brazil \\ E-mail: leticiafilice@gmail.com
}

\begin{abstract}
The aim of the present work was to assess the biological viability of two titanium surfaces treated by electric discharge machining (EDM) using water or hydroxyapatite as modifying agents and compare them to a machined titanium surface without modifying agent as a control. The in vitro MTT, total protein, alkaline phosphatase and alizarin red assays and scanning electron microscopy were applied to analyze pre-osteoblastic MC3T3-E1 cells after 7, 14 and 21 days of cell culture on the titanium surfaces. The results showed the presence of cellular activity in all surfaces and the formation of bone matrix, with no discrepancy among the groups. All tested surfaces were capable of inducing bone formation. In the topographic analysis of the surface, EDM failed to modify the surface of the discs homogeneously. Thus, EDM is a low-cost, biocompatible technique that favors osseointegration, but which still needs to be improved.
\end{abstract}

Keywords: Regenerative medicine; Titanium; EDM; Hydroxyapatite; MC3T3-E1.

\section{Resumo}

O objetivo do presente trabalho foi avaliar a biocompatibilidade de duas superfícies de titânio tratadas por descarga elétrica (EDM) utilizando água ou hidroxiapatita como agentes modificadores e comparando-as a uma superfície usinada de titânio sem agente modificador como controle. Foram realizados ensaios in vitro de MTT, proteína total, 
fosfatase alcalina e vermelho de alizarina, além de microscopia eletrônica de varredura para analisar o comportamento das células MC3T3-E1 pré-osteoblásticas após 7, 14 e 21 dias de cultivo celular nas superfícies de titânio. Os resultados permitiram verificar a presença de atividade celular em todas as superfícies e a formação de matriz óssea, não havendo discrepância entre os grupos. Todos as superfícies testadas foram capazes de induzir a formação óssea. $\mathrm{Na}$ análise topográfica da superfície, o EDM não conseguiu modificar a superfície dos discos de maneira homogênea. Assim, o EDM é uma técnica de baixo custo, biocompatível, que favorece a osteointegração, mas que ainda precisa ser aprimorada.

Palavras-chave: Medicina regenerativa; Titânio; EDM; Hidroxiapatita; MC3T3-E1.

\section{Resumen}

El objetivo del presente trabajo fue evaluar la viabilidad biológica de dos superficies de titanio tratadas mediante mecanizado por descarga eléctrica (EDM) utilizando agua o hidroxiapatita como agentes modificadores y comparándolas con una superficie mecanizada de titanio sin agente modificador como control. Se aplicaron ensayos in vitro de MTT, proteína total, fosfatasa alcalina y rojo de alizarina y microscopía electrónica de barrido para analizar células MC3T3-E1 preosteoblásticas después de 7, 14 y 21 días de cultivo celular en las superficies de titanio. Los resultados permitieron verificar la presencia de actividad celular en todas las superficies y la formación de matriz ósea, sin discrepancia entre los grupos. Todos los tipos de superficies testadas pueden inducir la formación de hueso. En el análisis topográfico de la superficie, el EDM no logró modificar la superficie de los discos de manera homogénea. Por tanto, la electroerosión es una técnica biocompatible de bajo coste que favorece la osteointegración, pero que todavía necesita ser mejorada.

Palabras clave: Medicina regenerativa; Titanio; EDM; Hidroxiapatita; MC3T3-E1.

\section{Introduction}

Bone is a living, vascularized and dynamic tissue that undergoes changes during life. The continuous bone remodeling provides a mechanism for the regeneration of damaged bone tissues and enables the balance of calcium and phosphate ions in the body through hormonal control (Davies, 2007).

Titanium has become the most widely used material in intraosseous implants (Hansson et al., 1983). Titanium has the capacity to undergo different types of treatment to improve the quality of the bone-implant interface and decrease the nonfunctional period of the implant (Osman \& Swain 2015). The findings of Hsu \& Chien (2016) and Kuo et al. (2021) showed that surface modification by the EDM technique may be an interesting approach. In EDM, an electric discharge generates a high temperature inside a column where a portion of the ionized substrate can be deposited on a machined surface at the end of the electric discharge interval (Pramanik et al., 2020). The electrode composition transfers and deposits on the machined surface to provide the modifying agent with a suitable surface. Thus, the use of a semi-sintered electrode may increase the effects of titanium surface modifications.

Understanding the process through which cells interact with materials is important in bioengineering. During osseointegration, bone cells adhere to the implant surface through the extracellular matrix (ECM) composed of proteins and proteoglycans. After a few seconds of contact between the surface and the interstitial fluid, the surface becomes coated with water and proteins, so the cells perceive the surface characteristics through this adsorbed layer of ECM (Anselme et al., 2010). In vitro studies have been used in cell-substrate interaction research to understand the effects of materials on the biological media in which they are inserted. This type of study is particularly useful for detailed analyses of cell behavior in contact with biomaterials, especially titanium (Galli et al., 2005).

This work aimed to evaluate the influence of EDM on titanium surfaces and its interaction with pre-osteoblastic cells MC3T3-E1 comparing two surfaces machined with modifying agents and a third one machined without modifying agents as a control.

\section{Methodology}

Discs made of a commercial titanium-aluminium-vanadium (Ti6Al4V) alloy (AST M B348 Grade V) were cut into 
discs of 2-mm thickness and 5-mm diameter and modified according to the proposed treatments provided by the Tribology and Materials Laboratory at the Federal University of Uberlândia (LTM-UFU). The composition and protocols for the thermal treatments of the discs are described in patents BR1020120305232 and BR1320140041121.

Three different types of surfaces were analyzed on 135 Ti6A14V discs: (i) surfaces machined without any modifying agent on 45 Ti6Al4V discs (control); (ii) surfaces machined by EDM using distilled water as a dielectric medium on 45 Ti6Al4V discs and; (iii) surfaces machined by EDM using hydroxyapatite (Ca10(PO4)6(OH)2) particles as a dielectric medium on 45 Ti6Al4V discs.

\section{Analysis and characterization of the dises}

Titanium discs were analyzed with scanning electron microscopy (SEM) at the LTM-UFU to identify surface topography.

\section{Culture of osteoblasts on titanium discs}

Pre-osteoblastic MC3T3-E1 cells were cultured in flasks with $\alpha$-MEM culture medium supplemented with $10 \%$ fetal bovine serum at $37^{\circ} \mathrm{C}$ and $5 \% \mathrm{CO} 2$. After reaching confluence, cells were plated on titanium alloy discs at a density of 3x104 cells/well in 96-well plates and cultured in osteogenic medium ( $\alpha$-MEM medium supplemented with dexamethasone, ascorbic acid and $\beta$-Glycerophosphate) for periods of 7, 14 and 21 days.

\section{Cell viability}

MC3T3-E1 cell cultures were tested for cell viability using the MTT assay on days 7, 14 and 21. The supernatant from each well was removed, cells were lysed and $10 \mathrm{ml}$ of MTT solution and $100 \mu \mathrm{l}$ of DMSO were added at room temperature. After solubilization of the crystals, quantification was performed on a Multiskan GO (Thermo Scientific-Finland) microplate reader.

\section{Determination of total protein}

The total protein content of MC3T3-E1 cells after 7, 14 and 21 days in culture was calculated with the modified Lowry method. Wells were washed three times with $0.1 \mathrm{M}$ phosphate buffer at $37^{\circ} \mathrm{C}$ and $2 \mathrm{ml}$ of $0.1 \%$ sodium lauryl sulfate were added. After 30 minutes, $1 \mathrm{ml}$ of this solution was collected from each well and incubated with $1 \mathrm{ml}$ of Lowry solution for 20 minutes at room temperature. Then, $0.5 \mathrm{ml}$ of Folin-Ciocalteau's phenol reagent was added and incubated for 30 minutes at room temperature for reading on an Ultraspec 1100 pro UV/visible spectrophotometer (Amersham Biosciences) at $680 \mathrm{~nm}$.

\section{Quantification of Alkaline Phosphatase (ALP)}

Alkaline Phosphatase Labtest@ kit was used to quantify the ALP activity of MC3T3-E1 cells on days 7, 14 and 21, according to the manufacturer's recommendations. After processing, samples were read on an Ultrospec 1100 pro UV/visible spectrophotometer (Amersham Biosciences) at $590 \mathrm{~nm}$.

\section{Analysis of cellular morphology with SEM}

Morphological analysis of the MC3T3-E1 cells was performed on days 7, 14 and 21. The supernatant was removed, and the discs were washed in $0.1 \mathrm{M}$ phosphate buffer and fixed in Karnovsky (2.5\% glutaraldehyde and $2 \%$ paraformaldehyde in $0.1 \mathrm{M}$ sodium cacodylate buffer at $\mathrm{pH}$ 7.4) for $1 \mathrm{~h}$. Then, the fixative was removed, and the discs were dehydrated in 
increasing concentrations of ethanol. After dehydration, the discs were dried and coated with three bimetal layers of goldpalladium for analysis under an EVO MA10 microscope (ZEISS).

\section{Results and Discussion}

Several studies have evaluated bone interaction with different types of surface treatment of titanium implants (Zambuzzi et al., 2014; Shi et al., 2017; Zhu et al.,2020; Tamayo et al., 2021). The interpretation of surface modifications is complex, since the alteration of microtopography also leads to the change of nanotopography, even if it is not previously planned (Zhu et al., 2020; Rosa et al., 2012). However, to assert the presence of nanotopography, it must be purpose-built, uniformly distributed and adequately characterized (Zambuzzi et al., 2014).

It is known that the creation of micro-roughness and incorporation of bioactive substances, such as calcium phosphate or morphogenic bone proteins, may accelerate and intensify bone formation around implants (Jeffcoat et al., 2003). In studies with commercially available titanium surface treatments, although the association of subtractive processes with calcium and phosphate coatings caused changes in the nanometric level of roughness, it was not able to modify the biological behavior of the surface in comparison with other types of treatment (Zambuzzi et al., 2014; Shi et al., 2017). This result coincides with that found in our study, since cell growth and proliferation on the surface machined with hydroxyapatite were similar to those obtained on the control surface and higher than those on the surface machined with water.

EDM requires simpler equipment than do other processes. The electrode composition is transferred and deposited on the machined surface during the process, modifying the surface to meet special demands for its performance. The process of surface modification by EDM generates different effects on the surface according to the dielectric fluids used. For example, a surface machined with kerosene forms a hardened and carbonized layer whereas one machined with distilled water forms a softened and decarbonized layer, according to (Chen et al., 2014).

The literature concerning EDM usage as a surface treatment is relatively sparse (Harcuba et al., 2012). To the best of our knowledge, the present study is the only one to compare titanium surfaces machined by EDM using modifying agents with a smooth titanium surface (machined without a modifying agent). This fact makes it difficult to compare our data with other similar results.

In addition to the difficulty of characterizing the surface treatments on the discs, we also found difficulties at the time of cell culture, when it comes to in vitro osseointegration. The disc format was chosen because it facilitates the accommodation of the surfaces in the wells, and it was also used by Moura et al. (2013) and Lumetti et al. (2016). MC3T3-E1 cells are immortalized cells from mouse calvaria, widely used in this type of studies (Zambuzzi et al., 2014; Lai et al., 2015). The main advantage of this cell line is its high proliferation capacity. However, its phenotype may be slightly different from the original tissue (Anselme et al., 2010).

In the present study, all tests were done on days 7, 14 and 21 using three culture plates containing 45 discs each. One culture plate was processed on each day and triplicates were used for each test. In order to determine the impact of the titanium surface treatment on in vitro cell biology, the MTT assay has been widely used (Ferreira et la., 2015; Matos et al., 2017). In this study, cell proliferation was similar among the experimental groups over the days, indicating that there are no cytotoxic effects. Cell proliferation was low in all samples on day 7 and increased significantly until day 21 (Figure 1). 
Figure 1: MTT assay showing statistically similar results for the three surfaces and in the three periods.

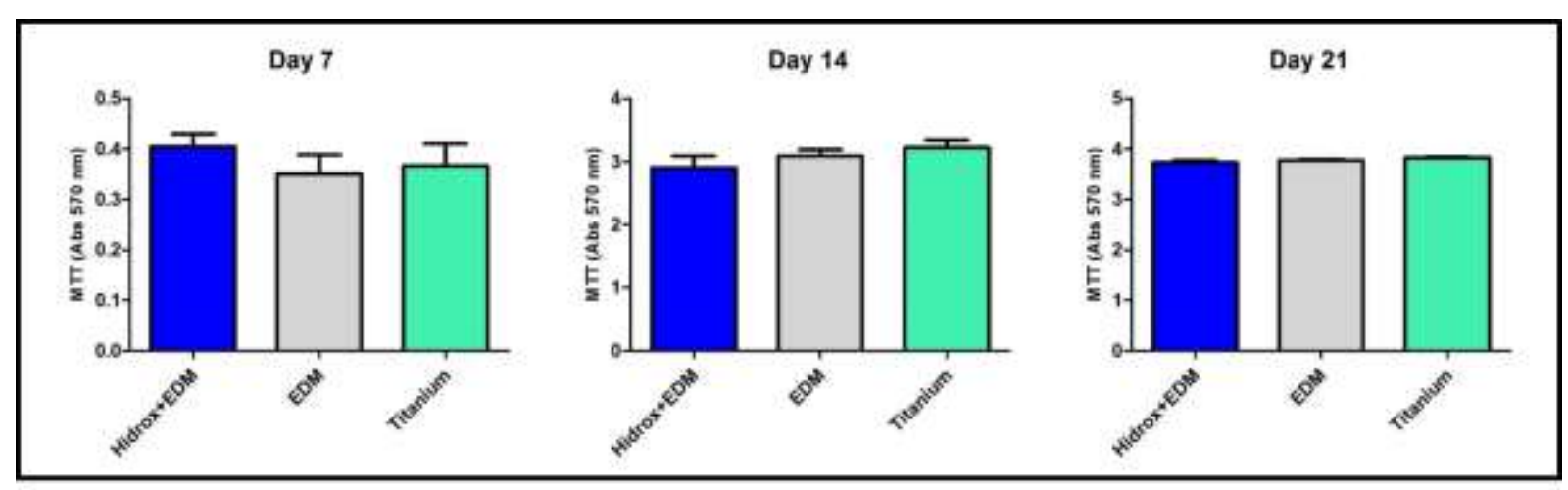

Source: Elaborated by the authors (2021).

In order to determine in vitro cellular viability and differentiation, ALP and Total protein production were also measured in response to titanium surface modifications (Figures 2 and 3). The biological response of osteoblasts to a titanium substrate is influenced by both surface roughness and chemotherapy (Subramani et al., 2016). The organization of the mineralized matrix on both the control surface and the surface machined with hydroxyapatite demonstrates the influence of the surface microtopography (roughness) on the cellular phenotype, being thus in agreement with other studies (Matos et al., 2017; Schwartz. 2009).

Figure 2: ALP assay demonstrating that activity of ALP was more intense in the first week in all surfaces, falling in the following weeks. However, the surfaces modified with hydroxyapatite showed higher activities compared with the others on day and compared with the control surface on day 21.

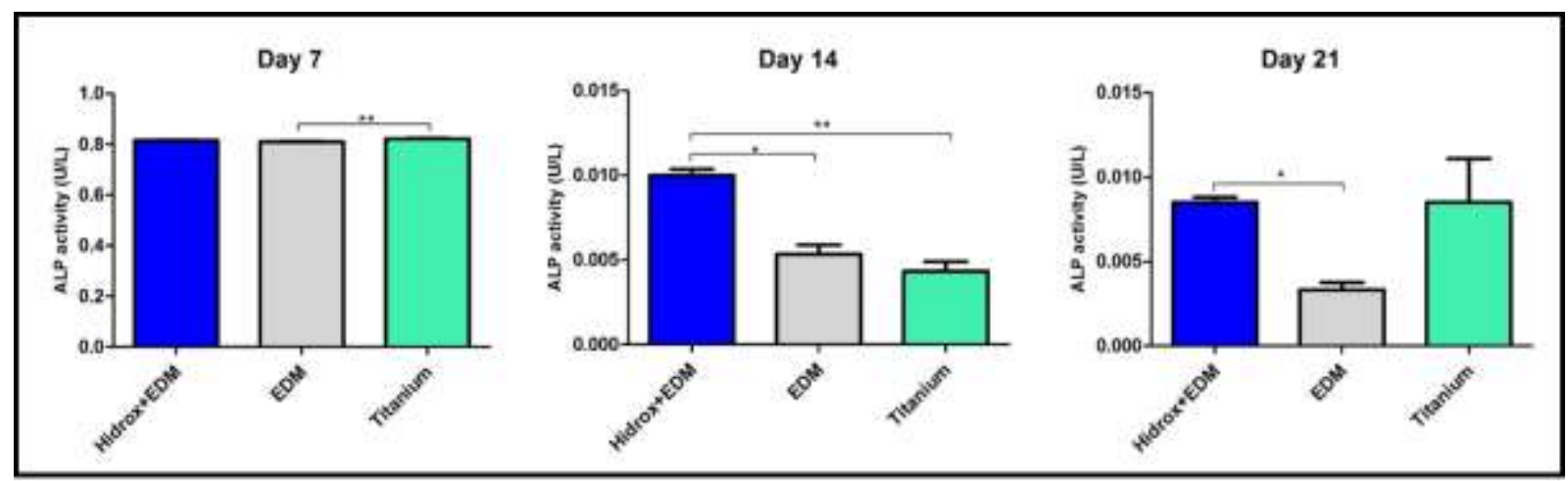

Source: Elaborated by the authors (2021). 
Figure 3: Total Protein assay - On day 7, no statistical difference was observed among the three surfaces. On day 14, there was a significant drop in all surfaces and the control surface had the lowest protein content. On day 21, there was no statistical difference.

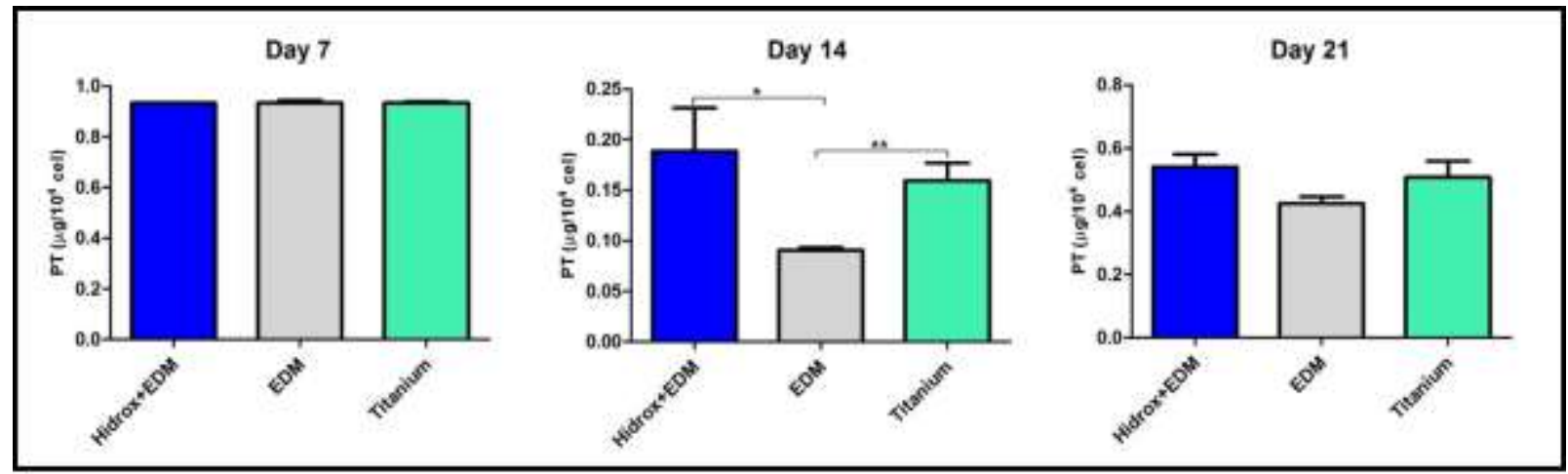

Source: Elaborated by the authors (2021).

The analysis of the discs through SEM allowed the visualization of important characteristics in the EDM process (Figures 4, 5 and 6). For example, the lack of homogeneity of the disc surfaces was shown in the specimens by the presence of a continuous layer of osteoblastic cells on the surface modified by hydroxyapatite and globular-like mineral deposits in association with ECM.

Figure 4: Scanning electron micrographs of MC3T3 cultured in surfaces machined without any modifying agent on Ti6Al4V discs at 7, 14 and 21 days.

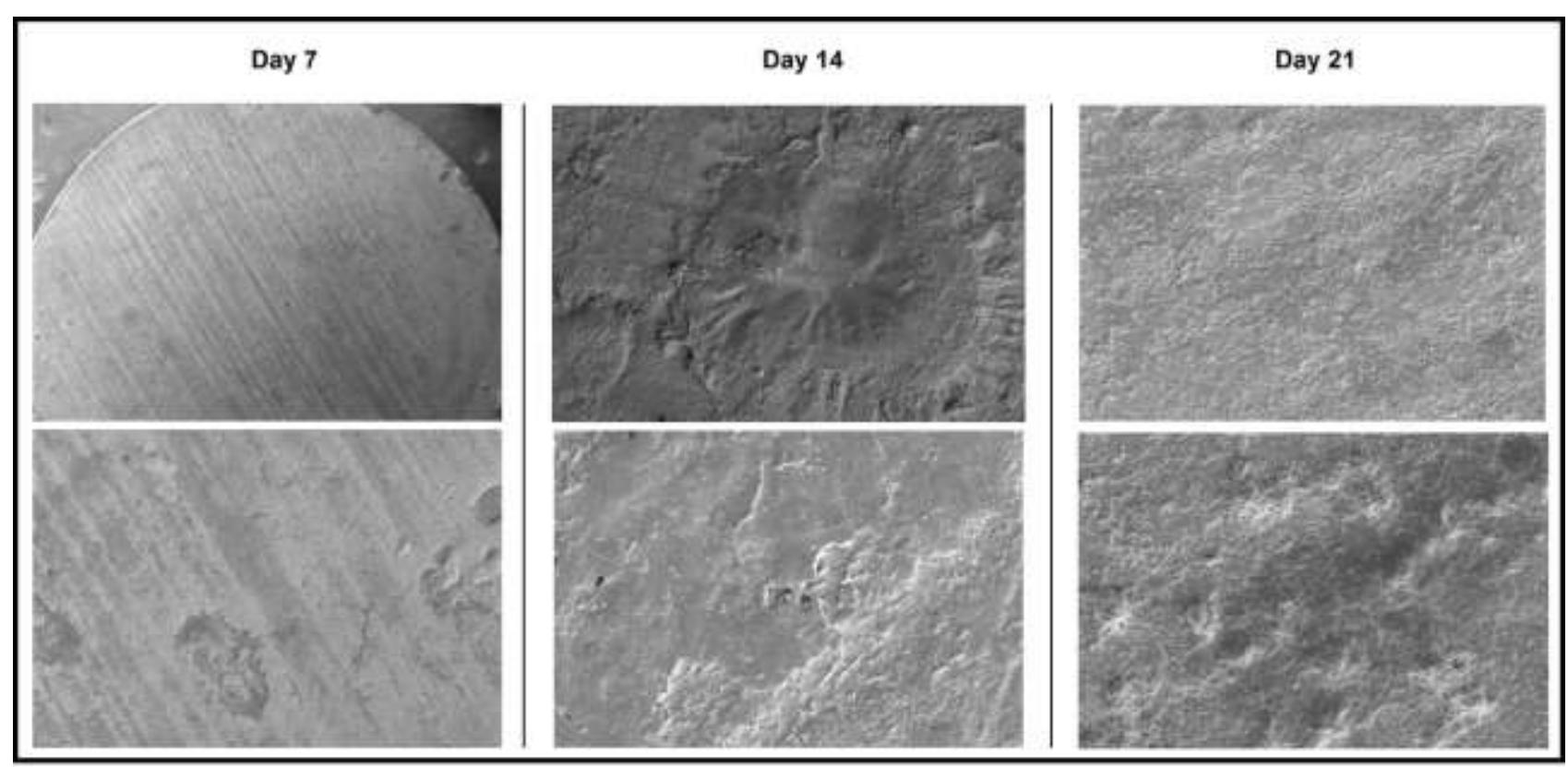

Source: Elaborated by the authors (2021). 
Figure 5: Scanning electron micrographs of MC3T3 cultured in surfaces machined by EDM using distilled water as a dielectric medium on Ti6Al4V discs at 7, 14 and 21 days.

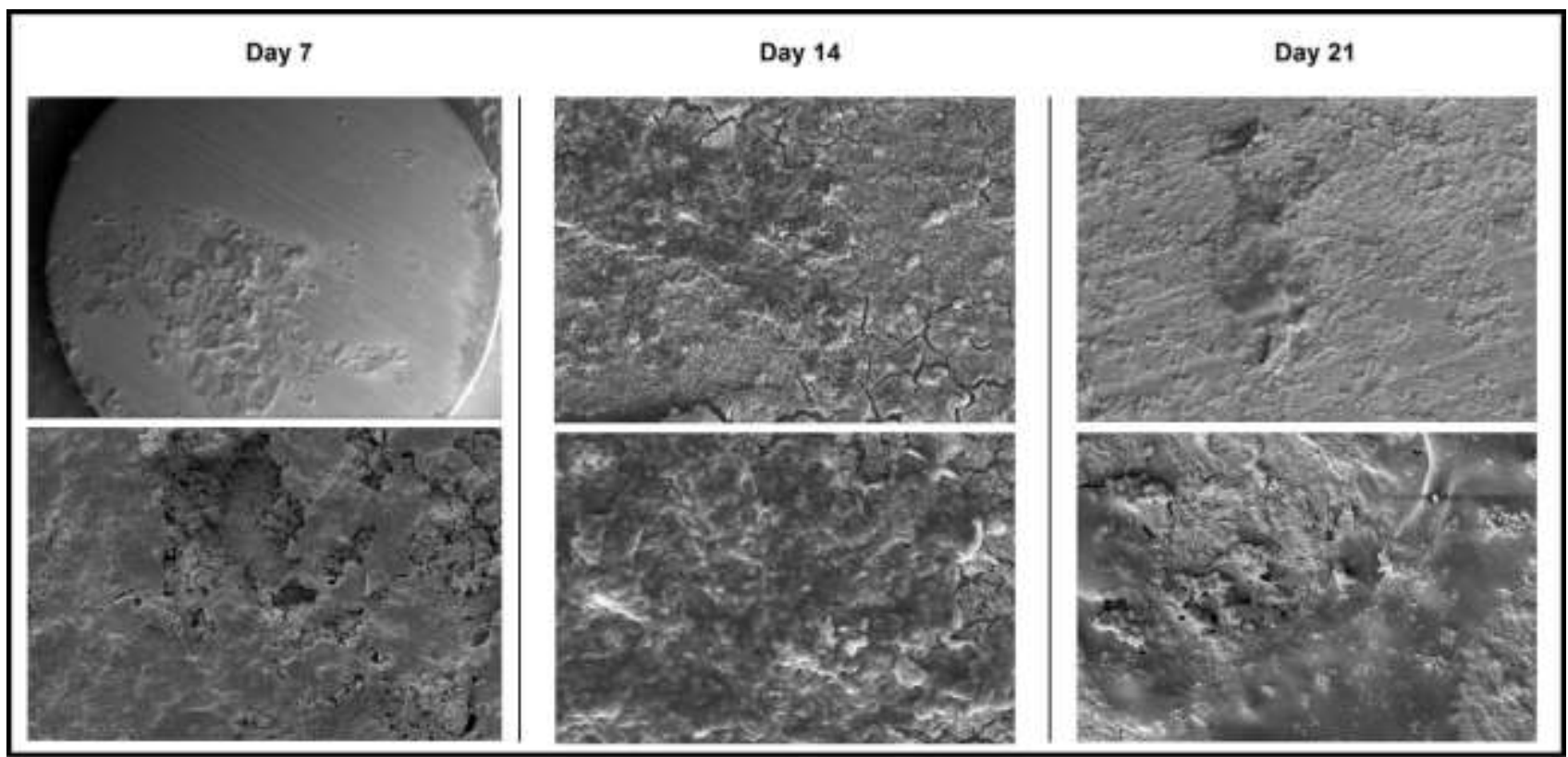

Source: Elaborated by the authors (2021).

Figure 6: Scanning electron micrographs of MC3T3 cultured in surfaces machined by EDM using hydroxyapatite $(\mathrm{Ca} 10(\mathrm{PO} 4) 6(\mathrm{OH}) 2)$ particles as a dielectric medium on Ti6Al4V discs at7, 14 and 21 days.

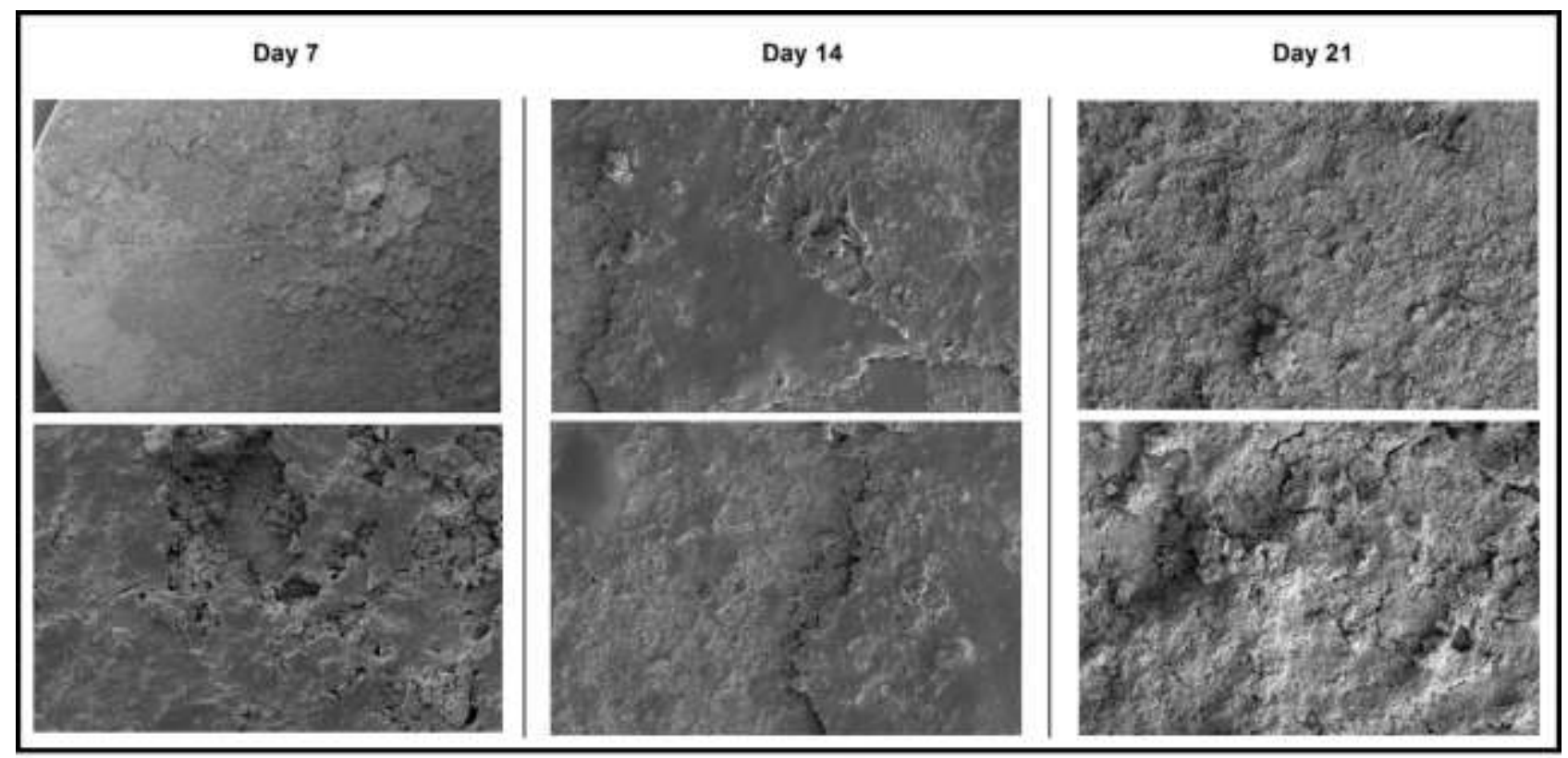

Source: Elaborated by the authors (2021).

The control surfaces (Figure 4) analyzed on day 7 showed a softer topography with shallow and parallel grooves resulting from the manufacturing process. At a higher magnification, it shows deeper and wider grooves irregularly interspersed with shallower and thinner grooves surrounded by small irregularities. In addition, there are spots with irregular edges and smooth appearance that suggest the presence of organic material. In spite of the smoother surface in the control 
group, a large group of adherent cells was observed at the 510x magnification. At the 3120x magnification, cells were grouped and covered superficial ridges of the surface, showing the cell compatibility of titanium. On day 14, organic material was identified and the initial process of mineralization on the control discs was observed. A smooth formation was observed, suggesting the presence of organic material surrounded by a rough and bumpy surface. At a higher magnification, the organic material (smooth surface) is observed more clearly; with irregular edges, rough irregular appearance and nodules, sugge stive of the mineralization process. On day 21 in the control group, discs showed expressive increases in topography with extensive coverage of the ripples of disc surfaces. A rough and uneven layer covers the surface. Two regions could be observed, one smooth and bright and another rough and opaque, suggesting that the mineralization process has not yet been completed. In addition, the crystallization peaks of the organic matrix were observed.

On discs modified by EDM using water (Figure 5), an irregular surface and a large portion of the surface apparently without treatment were observed. At a higher magnification, a smooth-looking material, irregularly adhered to the surface, suggests a failure in surface treatment.

On the discs modified by EDM using hydroxyapatite (Figure 6), the absence of total surface coverage was also observed in an overview image of a disc at a small magnification. However, at a higher magnification, a greater roughness on the surface relief and the presence of organic material on this surface were observed on day 7, both propitious to cell adhesion. On day 14 in the hydroxyapatite treatment group, this type of surfaces showed a larger grouping of cells (smooth surface) at an earlier stage of the formation of the protein matrix, when compared with the other surfaces on the same day. At a higher magnification, cellular extensions creating a mesh of organic material were visible. On day 21 , the surfaces modified by hydroxyapatite showed a well-structured protein matrix. The mineralization process was practically complete and more advanced than on the other surfaces. Surface roughness is barely noticeable at the $344 \mathrm{x}$ magnification and there is still difficulty at a higher magnification.

The present work showed that different surfaces provide favorable conditions for cell growth. Hydroxyapatite discs showed a faster cell growth rate in relation to the other discs when the degree of mineralization was analyzed on day 21 . Unfortunately, due to the difficulty of the EDM technique, the surfaces lack a homogeneous pattern of roughness, which may have contributed to the lower-than-expected results.

Based on cellular proliferation and differentiation responses, the aim of this study was to assess which of the surfaces would obtain better results in relation to osteoblastic cell behavior. The use of cells for the testing of implants and biomaterials in the fields of cellular engineering and therapy is seen as promising (Davies, 2007; Hansson et al., 1983). Therefore, this study agrees with the results previously reported about the use of cells for testing titanium surfaces and leaves an open field for further research following the methodology employed.

\section{Conclusion}

Although no statistically significant differences were observed among the treatments performed on the surfaces, we verify that all types of machined surfaces may be capable of inducing bone formation. In this work, we state that although EDM is a simple, economically, and biologically viable technique. However, the poor modification of titanium disc surfaces may have influenced the results. Thus, we conclude that there is a need for further studies to improve this technique allowing the homogenization of the titanium disc surfaces and consequently an appropriate industrial production of titanium implants.

\section{Acknowledgments}

The authors would like to thank FAPEMIG for the research grants (FAPEMIG APQ-03063-16). 


\section{References}

Anselme, K., Ponche, A., \& Bigerelle, M. (2010) Relative influence of surface topography and surface chemistry on cell response to bone implant materials. Part 2: biological aspects. Proc Inst Mech Eng H 224(12):1487-507. 10.1243/09544119JEIM901.

Chen, W. C., Chen, Y. S., Ho, C. L., Lin, Y., \& Kuo, H. N. (2014) Interaction of progenitor bone cells with different surface modifications of titanium implant. Mater Sci Eng C Mater Biol Appl 37: 305-13. 10.1016/j.msec.2014.01.022.

Davies, J. E. (2007). Bone bonding at natural and biomaterial surfaces. Biomaterials 28: 5058-5067. 10.1016/j.biomaterials.2007.07.049.

Ferreira, L. B., Bradaschia-Correa, V., Moreira, M. M., Marques, N. D., \& Arana-Chavez, V. E. (2015) Evaluation of bone repair of critical size defects treated with simvastatin-loaded poly (lactic-co-glycolic acid) microspheres in rat calvaria. J Biomater Appl 29(7):965-76. 10.1177/0885328214550897.

Galli, C., Guizzardi, S., Passeri, G., Martini, D., Tinti, A., Mauro, G., \& Macaluso, G. M. (2005) Comparison of Human Mandibular Osteoblasts Grown on Two Comercially Availabe Titanium Implant Surfaces. J Periodontol 76(3): 364-72. 10.1902/jop.2005.76.3.364.

Hansson, H. A., Albrektsson, T., \& Branemark, P. I. (1983) Structural aspects of the interface between tissue and titanium implants. J Prosthet Dent 50(1):108-113. 10.1016/0022-3913(83)90175-0.

Harcuba, P., Bačáková, L., Stráský, J., Bačáková, M., Novotná, K., \& Janeček, M. J. Surface treatment by electric discharge machining of Ti-6Al-4V alloy for potential application in orthopaedics. Mech Behav Biomed Mater. 96-105. 10.1016/j.jmbbm.2011.07.001.

Hsu, W. H., \& Chien, W. T. (2016) Effect of Electrical Discharge Machining on Stress Concentration in Titanium Alloy Holes. Materials (Basel). 24,9(12). $10.3390 / \mathrm{ma} 9120957$.

Jeffcoat, M. K., McGlumphy, E. A., Reddy, M. S., Geurs, N. C., \& Proskin, H. M. (2003) A comparison of hydroxyapatite (HA) -coated threaded, HA-coated cylindric, and titanium threaded endosseous dental implants. Int J Oral Maxillofac Implants 18(3):406-10.

Kuo, C., Nien, Y., Chiang, A., \& Hirata, A. (2021) Surface Modification Using Assisting Electrodes in Wire Electrical Discharge Machining for Silicon Wafer Preparation. Materials, 14, 1355. 10.3390/ma14061355.

Lai, M., Hermann, C. D., Cheng, A., Olivares-Navarrete, R., Gittens, R. A., \& Bird, M. M. Role of $\alpha 2 \beta 1$ integrins in mediating cell shape on microextured titanium surfaces. J Biomed Mater Res A 103(2):564-73. 10.1002/jbm.a.35185.

Lumetti, S., Manfredi, E., Ferraris, S., Spriano, S., Passeri, G., Ghiacci, G., Macaluso, G., \& Galli, C. (2016) The response of osteoblastic MC3T3-E1 cells to micro- and nano- textured, hydrophilic, and bioactive titanium surfaces. J Mater Sci: Mater Med 27:68. 10.1007/s10856-016-5678-5.

Matos, A. O., Ricomini-Filho, A. P., Beline, T., Ogawa, E. S., Costa-Oliveira, B. E., de Almeida, A. B., Nociti Junior, F. H., Rangel, E. C., da Cruz, N. C., Sukotjo, C., Mathew, M. T., \& Barão, V. A. (2017) Three-species biofilm model onto plasma-treated titanium implant surface. Colloids Surf B Biointerfaces 1,152:354-366. 10.1016/j.colsurfb.2017.01.035.

Moura, C. G., Souza, M. A., Kohal, R. J., Dechichi, P., Zanetta-Barbosa, D., Jimbo, R., Teixeira, C. C., Teixeira, H. S., Tovar, N., \& Coelho, P. G. (2013) Evaluation of osteogenic cell culture and osteogenic/peripheral blood mononuclear human cell co-culture on modified titanium surfaces. Biomed Mater 8(3):035002. 10.1088/1748-6041/8/3/035002.

Osman, R. B., \& Swain, M. V. (2015). A Critical Review of Dental Implant Materials with an Emphasis on Titanium versus Zirconia. Materials (Basel, Switzerland), 8(3), 932-958. 10.3390/ma8030932.

Pramanik, A., Basak, A.K., Littlefair, G., Debnath, S., Prakash, C., Singh, M. A., Marla, D., \& Singh, R. K. Methods and variables in Electrical discharge machining of titanium alloy - A review. Heliyon. 2020 Dec 14,6(12):e05554. 10.1016/j.heliyon.2020.e05554.

Rosa, M. B., Albrektsson, T., Francischone, C. E., Schwartz Filho, H. O., \& Wennerberg, A. (2012) The influence of surface treatment on the implant roughness pattern. J Appl Oral Sci 20(5):550-5. 10.1590/s1678-77572012000500010.

Schwartz, Z., Olivares-Navarrete, R., Wieland, M., Cochran, D. L., \& Boyan, B. D. (2009) Mechanisms regulating increased production of osteoprotegerin by osteoblasts cultured on microstructured titanium surface. Biomaterials 30(20):3390-6. 10.1016/j.biomaterials.2009.03.047.

Shi, Q., Qian, Z., Liu, D., \& Liu, H. (2017) Surface Modification of Dental Titanium Implant by Layer-by-Layer Electrostatic Self-Assembly. Front Physiol 7,8: 574. 10.3389/fphys.2017.00574.

Subramani, K., Pandruvada, S. N., Puleo, D. A., Hartsfield Jr., J. K., \& Huja, S. S. (2016) In vitro evaluation of osteoblast responses to carbon nanotubecoated titanium surfaces. Progress in Orthodontics 17(1):23. 10.1186/s40510-016-0136-y.

Tamayo, J. A., Riascos, M., Vargas, C. A., \& Baena, L. M. (2021). Additive manufacturing of Ti6Al4V alloy via electron beam melting for the development of implants for the biomedical industry. Heliyon, 7(5), e06892. 10.1016/j.heliyon.2021.e06892.

Zambuzzi, W.F., Bonfante, E. A., Jimbo, R., Hayashi, M., Anderson, M., Alves, G., Takamori, E. R., Beltrão, P. J., Coelho, P. G., \& Granjeiro, J. M. (2014) Nanometer Scale Titanium Surface Texturing Are Detected by Signaling Pathways Involving Transient FAK and Src Activations. PLoS One 9(7): e95662. 10.1371/journal.pone.0095662.

Zhu, Z., Guo, D., Xu, J., Lin, J., Lei, J., Xu, B., Wu, X., \& Wang, X. (2020) Processing Characteristics of Micro Electrical Discharge Machining for Surface Modification of TiNi Shape Memory Alloys Using a TiC Powder Dielectric. Micromachines (Basel).20 11(11):1018. 10.3390/mi11111018. 